\title{
O przewodności cieplnej meteorytu Jezersko
}

\section{The thermal conductivity of the Jezersko meteorite}

\author{
Marian A. Szurgot \\ Centrum Nauczania Matematyki i Fizyki Politechniki Łódzkiej
}

\begin{abstract}
STRESZCZENIE: Praca prezentuje wyniki przewidywań teoretycznych przewodności cieplnej $(K)$ meteorytu Jezersko, sklasyfikowanego jako chondryt zwyczajny H4. Przewidywania oparto na wybranych modelach skał i różnych zależnościach teoretycznych i empirycznych. Wykorzystano skład modalny chondrytu Jezersko ustalony przez autora oraz literaturowe dane o przewodności cieplnej minerałów składowych meteorytu i jego porowatości $(P)$. Stosując wymienione metody, określono przewodność cieplną szkieletu ziarnowego meteorytu i jego globalną przewodność cieplną, wykorzystując także przewidywane wartości dyfuzyjności cieplnej $(D)$. Wyniki potwierdzają znane prawidłowości dotyczące skał ziemskich i meteorytów, że współczynnik porowatości skały i materia wypełniająca pory silnie wpływają na przewodność cieplną. Model średniej geometrycznej przewiduje dla szkieletu ziarnowego meteorytu Jezersko wartość przewodności cieplnej $4,35 \mathrm{~W} \mathrm{~m}^{-1} \mathrm{~K}^{-1}$, a średnia $\mathrm{z}$ dwóch modeli warstwowych: modelu średniej harmonicznej i modelu średniej arytmetycznej wartość $4,9 \mathrm{~W} \mathrm{~m}^{-1} \mathrm{~K}^{-1}$ dla temperatury $300 \mathrm{~K}$. Globalna przewodność cieplna meteorytu Jezersko $(K)$ według modelu średniej geometrycznej w temperaturze $300 \mathrm{~K}$ wynosi $2,6 \mathrm{~W} \mathrm{~m}^{-1} \mathrm{~K}^{-1}$ dla ciśnienia powietrza 1 atm, a $1,0 \mathrm{~W} \mathrm{~m}^{-1} \mathrm{~K}^{-1}$ dla próżni. Model Hashina-Shtrikmana przewiduje wartości $K: 2,4 \mathrm{~W} \mathrm{~m}^{-1} \mathrm{~K}^{-1}$ i $1,9 \mathrm{~W} \mathrm{~m}^{-1} \mathrm{~K}^{-1}$, model Clausiusa-Mossottiego - wartości: $2,2 \mathrm{~W} \mathrm{~m}^{-1} \mathrm{~K}^{-1}$ i $1,9 \mathrm{~W} \mathrm{~m}^{-1} \mathrm{~K}^{-1}$, natomiast modele warstwowe skał - wartości: $2,1 \mathrm{~W} \mathrm{~m}^{-1} \mathrm{~K}^{-1}$ i $2,0 \mathrm{~W} \mathrm{~m}^{-1} \mathrm{~K}^{-1}$ dla temperatury $300 \mathrm{~K}$ i powietrza pod ciśnieniem $1 \mathrm{~atm}$ oraz dla próżni. Zależność pomiędzy przewodnością cieplną i porowatością wskazuje średnią wartość $K$ dla meteorytu Jezersko dla próżni: $1,18 \mathrm{~W} \mathrm{~m}^{-1} \mathrm{~K}^{-1}$, a zależność pomiędzy przewodnością cieplną i dyfuzyjnością cieplną wskazuje wartość $K$ : $1,12 \mathrm{~W} \mathrm{~m}^{-1} \mathrm{~K}^{-1}$ dla zakresu $200-300 \mathrm{~K}$ dla próżni, a w przypadku powietrza pod ciśnieniem normalnym wartość: $2,57 \mathrm{~W} \mathrm{~m}^{-1} \mathrm{~K}^{-1}$. Średnia wartość przewodności cieplnej chondrytu Jezersko dla wszystkich przewidywań wynosi w przypadku temperatury $300 \mathrm{~K}$ i ciśnienia powietrza $1 \mathrm{~atm}: 2,45 \pm 0,30 \mathrm{~W} \mathrm{~m}^{-1} \mathrm{~K}^{-1}$, a w przedziale temperatur 200-300 $\mathrm{K}$ i próżni: $1,40 \pm 0,40 \mathrm{~W} \mathrm{~m}^{-1} \mathrm{~K}^{-1}$. Przewidywane wartości globalnej przewodności cieplnej meteorytu Jezersko dla powietrza i próżni są w zakresie wartości ostatnio prezentowanych przez Soini i in. (2020) dla grupy $\mathrm{H} 4$ chondrytów zwyczajnych: 2,8 $\pm 0,6 \mathrm{~W} \mathrm{~m}^{-1} \mathrm{~K}^{-1}$, wartość średnia $K$ przy wypełnieniu porów przez powietrze pod ciśnieniem $1 \mathrm{~atm}$, oraz $1,9 \pm 1,0 \mathrm{~W} \mathrm{~m}^{-1} \mathrm{~K}^{-1}$, wartość średnia $K$ dla zakresu temperatur: 200-300 K, gdy ośrodkiem wypełniającym pory jest próżnia.
\end{abstract}

Słowa kluczowe: meteoryt Jezersko, chondryty zwyczajne, przewodność cieplna.

ABSTRACT: The thermal conductivity $(K)$ of Jezersko H4 meteorite was predicted by various models of rocks, using literature data on the chemical composition, porosity $(P)$, and by relationships between thermal conductivity and porosity, and between thermal conductivity and thermal diffusivity $(D)$. The results confirm that the porosity of the chondrite and air pressure significantly affect thermal conductivity. The thermal conductivity of the chondrite skeleton/matrix predicted by the modal composition of the meteorite and by the geometric mean model is equal to $4.35 \mathrm{~W} \mathrm{~m}^{-1} \mathrm{~K}^{-1}$, and by arithmetic and harmonic mean models: $4.9 \mathrm{~W} \mathrm{~m}^{-1} \mathrm{~K}^{-1}$ at $300 \mathrm{~K}$. Bulk thermal conductivity of the meteorite predicted by the geometric mean model is equal to $2.6 \mathrm{~W} \mathrm{~m}^{-1} \mathrm{~K}^{-1}$ for air pressure of 1 atm, and $1.0 \mathrm{~W} \mathrm{~m}^{-1} \mathrm{~K}^{-1}$ in vacuum at $300 \mathrm{~K}$. The Hashin-Shtrikman model predicts the values: 2.4 and $1.9 \mathrm{~W} \mathrm{~m}^{-1} \mathrm{~K}^{-1}$, the Clausius-Mossotti model: 2.2 and $1.9 \mathrm{~W} \mathrm{~m}^{-1} \mathrm{~K}^{-1}$, and the mean of two-layer models: 2.1 and $2.0 \mathrm{~W} \mathrm{~m}^{-1} \mathrm{~K}^{-1}$ at $300 \mathrm{~K}$, for air pressure of 1 atm, and in vacuum, respectively. The relationships between thermal conductivity and porosity based on experimental data for ordinary chondrites indicate a mean $K$ value for bulk thermal conductivity of the Jezersko meteorite in vacuum: $1.18 \mathrm{~W} \mathrm{~m}^{-1} \mathrm{~K}^{-1}$, and between thermal conductivity and thermal diffusivity the mean value: $1.12 \mathrm{~W} \mathrm{~m}^{-1} \mathrm{~K}^{-1}$ at $200-300 \mathrm{~K}$. The mean value for all predictions for bulk thermal conductivity of the meteorite for air at $1 \mathrm{~atm}$ is equal to $2.45 \pm 0.30 \mathrm{~W} \mathrm{~m}^{-1} \mathrm{~K}^{-1}$ (range: $2.0-2.9 \mathrm{~W} \mathrm{~m}^{-1} \mathrm{~K}^{-1}$ ) at $300 \mathrm{~K}$, and in vacuum: $1.40 \pm 0.40 \mathrm{~W} \mathrm{~m}^{-1} \mathrm{~K}^{-1}$ (range: $0.95-2.0 \mathrm{~W} \mathrm{~m}^{-1} \mathrm{~K}^{-1}$ ) at 200-300 K. Predicted values of bulk thermal conductivity of the Jezersko meteorite, for air and in vacuum, are in the range of values recently reported by Soini et al. (2020) for the H4 group of chondrites: $2.8 \pm 0.6 \mathrm{~W} \mathrm{~m}^{-1} \mathrm{~K}^{-1}$, mean $K$ for air at $1 \mathrm{~atm}$, and $1.9 \pm 1.0 \mathrm{~W} \mathrm{~m}^{-1} \mathrm{~K}^{-1}$ mean $K$ value in vacuum at $200-300 \mathrm{~K}$.

Key words: Jezersko meteorite, ordinary chondrites, thermal conductivity.

Autor do korespondencji: M.A. Szurgot, e-mail: maszurgot@gmail.com

Artykuł nadesłano do Redakcji: 01.10.2020 r. Zatwierdzono do druku: 11.01.2021 r. 


\section{Wstęp}

Właściwości termofizyczne skał pozaziemskich stanowią ważne źródło wiedzy o ciałach macierzystych meteorytów: planetoid i planet, są one potrzebne do tworzenia modeli budowy wewnętrznej ciał macierzystych meteorytów i ich ewolucji. Właściwości geochemiczne ciał macierzystych pozwalają na oszacowanie pozaziemskich zasobów surowcowych i wskazanie potencjalnych miejsc eksploatacji cennych surowców, niezbędnych dla obecnych i przyszłych potrzeb cywilizacyjnych mieszkańców Ziemi. Zwłaszcza planetoidy bogate w rzadkie w ziemskiej skorupie pierwiastki oraz metale ciężkie: żelazo, kobalt i nikiel są przedmiotem najnowszych badań, ukierunkowanych na przyszłe górnictwo pozaziemskie (Łuszczek i Przylibski, 2019). Chondryty zwyczajne należące do grupy $\mathrm{H}$, tj. chondryty o dużej zawartości żelaza, są szczególnie ważnym obiektem zainteresowań - zarówno dla planetologii, geologii, jak i górnictwa pozaziemskiego. Właściwości cieplne planetoid, planet i komet są integralną częścią wcześniejszych i obecnie realizowanych misji kosmicznych. Badania właściwości fizycznych i termofizycznych meteorytów i ich ciał macierzystych są prowadzone w wielu ośrodkach naukowych (Matsui i Osako, 1979; Osako, 1981; Yomogida i Matsui, 1983; Opeil et al., 2010, 2012, 2020; Szurgot, 2011, 2020a; Szurgot i Wojtatowicz, 2011; Henke et al., 2012, 2016; Flynn et al., 2018; Ostrowski i Bryson, 2019; Soini et al., 2020).

Przewodność cieplna, znana też jako współczynnik przewodnictwa cieplnego, to jedna z ważniejszych właściwości termofizycznych. Reprezentuje ona zdolność substancji do transportu ciepła i rządzi przepływem ciepła przez materiał w stanie ustalonym. Wielkość ta występuje w prawie Fouriera opisującym szybkość przewodzenia ciepła w materiałach stałych przy ustalonym przepływie ciepła:

$$
q=-K \cdot \operatorname{grad} T=-K \cdot d T / d z
$$

gdzie: $q\left[\mathrm{~W} / \mathrm{m}^{2}\right]$ jest gęstością strumienia cieplnego, $d T / d z-$ gradientem temperatury wytworzonym $w$ tym materiale/skale w laboratorium lub zmierzonym w otworze wiertniczym, $K$ jest współczynnikiem przewodnictwa cieplnego, a $z$ jest współrzędną osi, głębokością w przypadku otworów geologicznych. Przewodność cieplna $K$ jest mierzona w W/(m · K) i określa szybkość przepływu ciepła, tj. ilość ciepła przechodzącego przez ośrodek skalny na drodze jednego metra w czasie jednej sekundy, w kierunku prostopadłym do danego przekroju o powierzchni $1 \mathrm{~m}^{2}$, przy gradiencie temperatury $1 \% \mathrm{~m}$. Przewodność cieplna może być określona przez pomiar bezpośredni lub wyznaczona pośrednio poprzez teoretyczne i empiryczne zależności łączące ją z innymi wielkościami fizycznymi. Znajomość przewodności cieplnej różnorodnych substancji jest ważna dla wielu gałęzi nauki i techniki, zwłaszcza dla geologii, petrofizyki oraz planetologii. Znajomość współczynnika przewodnictwa cieplnego $K$ skał ziemskich i pozaziemskich pozwala określić gradient geotermalny, tj. gradient temperatury występujący w danej skale, oraz strumień ciepła przepływający w środowisku skalnym (Plewa i Plewa, 1992; Szewczyk, 2001; Fuchs et al., 2013, 2015; Przelaskowska, 2018). Badane są rdzenie wiertnicze wydobyte $\mathrm{z}$ różnych formacji skalnych (Szewczyk, 2001; Szewczyk i Gientka, 2009) i określane są ich profile przewodności cieplnej. Wyznaczenie gęstości powierzchniowej strumienia cieplnego Ziemi i tworzenie map jego rozkładu (Szewczyk i Gientka, 2009) ma zasadnicze znaczenie dla pozyskania i wykorzystania energii geotermalnej w danym regionie geograficznym.

Meteoryt Jezersko znaleziono w roku 1992 w paśmie górskim Karawanki w Słowenii, w kotlinie Spodnje Ravni w pobliżu schroniska turystycznego Češka koča (szerokość geograficzna/długość geograficzna: $\left.46^{\circ} 22^{\prime} 10.02^{\prime \prime} \mathrm{N} / 14^{\circ} 32^{\prime} 7.02^{\prime \prime} \mathrm{E}\right)$ i sklasyfikowano jako średnio zszokowany S2(3) chondryt zwyczajny H4 o umiarkowanym stopniu zwietrzenia W2 (Miler et al., 2014). Dotychczasowe badania właściwości fizycznych meteorytu Jezersko objęły gęstość objętościową (Miler et al., 2014), gęstość ziaren, średni ciężar atomowy i stosunek atomowy Fe/Si (Szurgot, 2019), a także średni ciężar cząsteczkowy, liczbę atomów w cząsteczce oraz objętość i promień atomu i cząsteczki tego meteorytu (Szurgot, 2020b). Ciepłu właściwemu, objętościowej pojemności cieplnej i ciepłu atomowemu meteorytu Jezersko była poświęcona oddzielna praca (Szurgot, 2020a). Celem prezentowanych badań było przewidywanie i zanalizowanie przewodności cieplnej chondrytu Jezersko.

\section{Metody badań}

Przewidywania oparto na wybranych modelach skał oraz zależnościach eksperymentalnych odkrytych dla materii meteorytów i skał ziemskich oraz na danych eksperymentalnych dotyczących meteorytu Jezersko i chondrytów zwyczajnych. Do przewidywań przewodności cieplnej wykorzystano modele warstwowe skał: model średniej arytmetycznej i model średniej harmonicznej, a także inne modele: model HashinaShtrikmana (HS), model inkluzji sferycznych ClausiusaMossottiego oraz empiryczny model średniej geometrycznej (Hashin i Shtrikman, 1962; Schön, 2011). Wykorzystano skład modalny chondrytu Jezersko ustalony przez autora oraz literaturowe dane o przewodności cieplnej minerałów składowych meteorytu i jego porowatości. Stosując wymienione metody, określono przewodność cieplną szkieletu ziarnowego meteorytu i całkowitą przewodność cieplną chondrytu, którą 
zweryfikowano, wykorzystując zależności łączące tę właściwość fizyczną z porowatością oraz z dyfuzyjnością cieplną. Przyjęto, że współczynnik przewodności cieplnej materii meteorytu Jezersko jest izotropowy.

\section{Wyniki badań i dyskusja}

Przewodność cieplna meteorytów i skał ziemskich zależy od przewodności ich składników mineralnych, przewodności gazu lub/i cieczy w porach i od geometrii i stopnia porowatości (Farouki, 1986; Schön, 2011; Soini et al., 2020). W pierwszym etapie przewidywań wykorzystano model średniej geometrycznej, według którego przewodność cieplna skały i innych ciał dwu- oraz wieloskładnikowych jest średnią geometryczną przewodności cieplnej jej składników. Meteoryt podzielono na dwie składowe. Pierwszą są minerały krzemianowe i metaliczne tworzące chondry oraz rozproszoną, drobnokrystaliczną frakcję tej skały. Drugą składową są substancje wypełniające pory. W pracy przyjęto, że skała jest sucha, a pory są wypełnione wyłącznie powietrzem pod ciśnieniem normalnym $\left(1 \mathrm{~atm} \approx 10^{5} \mathrm{~Pa}\right)$ albo powietrzem rozrzedzonym, znajdującym się pod ciśnieniem $10^{-5} \mathrm{~Pa}$ w warunkach bliskich próżni lub przy innych niskich ciśnieniach, jakie mogą występować na planetoidach.

Według modelu średniej geometrycznej dla mieszaniny dwuskładnikowej złożonej z ziaren o przypadkowej orientacji i przypadkowym rozkładzie przestrzennym całkowita przewodność cieplna $K$ skały meteorytu jest wyrażona zależnością:

$$
K=K s^{1-P} \cdot K f^{P}
$$

gdzie: $K s$ to wypadkowa przewodność cieplna składników mineralnych meteorytu tworzących szkielet skały (Woodside i Messmer, 1961; Nobes et al., 1986; Griffiths et al., 1992; Schön, 2011). Ta frakcja meteorytu w badaniach cieplnych skał $\mathrm{i}$ innych materiałów wieloskładnikowych jest określana jako szkielet skalny, szkielet ziarnowy lub matrix. Występująca we wzorze (2) wielkość $K f$ to przewodność cieplna płynu: gazu lub/i cieczy wypełniających pory, a $P$ to współczynnik porowatości meteorytu.

Przewodność cieplną szkieletu skalnego $K s$ określono, wykorzystując zmodyfikowany model średniej geometrycznej (Drury i Jessop, 1983; Farouki, 1986), model empiryczny dla $n$-składników. Model ten wykorzystuje średnią geometryczną wkładu indywidualnych minerałów budujących skałę:

$$
K s=\Pi_{i} K i^{V i}
$$

gdzie: $K i$ to przewodność cieplna $i$-tego składnika ( $i$-tego minerału), a $V i$ to udział objętościowy tego składnika w skale. Przy uwzględnieniu wszystkich składników skały $\Sigma V i=1$, a dla najważniejszych składników suma ta jest bliska jedynce. Model ten stosowano głównie dla ziemskich skał osadowych (Griffiths et al., 1992; Clauser i Huenges, 1995; Schön, 2011; Fuchs et al., 2015; Przelaskowska, 2018), a ostatnio dla chondrytów (Soini et al., 2020).

W obecnej pracy, podobnie jak i we wcześniejszych publikacjach opisujących właściwości cieplne meteorytów (Yomogida i Matsui, 1983; Soini et al., 2020), do obliczeń wykorzystano najbardziej rozpowszechnione w tej skale minerały skałotwórcze. Przewidywania przewodności cieplnej części szkieletowej meteorytu Jezersko oparto na sześciu minerałach chondrytu Jezersko: oliwinie (ol), ortopiroksenie (opx), klinopiroksenie (cpx), plagioklazie (pl), troilicie (tr) oraz minerałach metalicznych: kamacycie, taenicie i tetraenicie, tj. stopach Fe-Ni-Co oznaczonych łącznie jako metal. Wzór (3) przyjmuje postać:

$K s=K o l^{V o l} \cdot K_{o p x^{V o p x}} \cdot \mathrm{Kcpx}^{V c p x} \cdot \mathrm{Kpl}^{\mathrm{Vpl}} \cdot \mathrm{Ktr}^{\mathrm{Vtr}} \cdot \mathrm{Kmetal}^{\mathrm{Vmetal}}$

gdzie: przewodności cieplne minerałów składowych oznaczono jako: Kol, Kopx, Kcpx, Kpl, Ktr i Kmetal, a wykładniki potęg stanowią część objętości meteorytu zajętą przez dany minerał: oliwin $(V o l)$, ortopiroksen (Vopx), klinopiroksen $(V c p x)$, plagioklaz $(V p l)$, troilit (Vtr) oraz metal (Vmetal). Suma objętości tych sześciu głównych składników chondrytu Jezersko reprezentuje 99\% objętości całej materii skalnej meteorytu. Wykorzystanie wartości liczbowych: literaturowych danych o przewodności cieplnej minerałów budujących skałę: $K o l=$ $4,3 \mathrm{~W} \mathrm{~m}^{-1} \mathrm{~K}^{-1}$, Kopx $=3,9 \mathrm{~W} \mathrm{~m}^{-1} \mathrm{~K}^{-1}, K c p x=4,6 \mathrm{~W} \mathrm{~m}^{-1} \mathrm{~K}^{-1}$, $K p l=1,9 \mathrm{~W} \mathrm{~m}^{-1} \mathrm{~K}^{-1}, K t r=4,6 \mathrm{~W} \mathrm{~m}^{-1} \mathrm{~K}^{-1}$ (Yomogida i Matsui, 1983) i Kmetal $=28,1 \mathrm{~W} \mathrm{~m}^{-1} \mathrm{~K}^{-1}$ (Ho et al., 1978) oraz danych własnych autora uzyskanych dla składu modalnego chondrytu Jezersko: $V o l=0,32, \operatorname{Vopx}=0,324, V c p x=0,092, V p l=0,136$, $V t r=0,032$ oraz Vmetal $=0,086$ (tab. 1) prowadzi do uzyskania przewodności cieplnej szkieletu skalnego chondrytu Jezersko $K s=4,35 \pm 0,43 \mathrm{~W} \mathrm{~m}^{-1} \mathrm{~K}^{-1}$. Przyjęto tutaj, że błąd względny określenia $K s$ wynosi $10 \%$.

Równanie (2) można przekształcić do postaci:

$$
K=K s \cdot(K f / K s)^{P}
$$

w której występuje stosunek $K f / K s$. Gdy czynnik $(K f / K s)^{P}$ jest mały, wtedy globalna przewodność cieplna meteorytu jest także mała. Dzieje się tak wtedy, gdy stosunek $K f / K s$ jest mały lub/i porowatość meteorytu $P$ jest duża. Podstawienie do wzoru (5) wartości liczbowych: $K f(1 \mathrm{~atm})=0,026 \mathrm{~W} \mathrm{~m}^{-1} \mathrm{~K}^{-1}$ dla powietrza w warunkach $1 \mathrm{~atm}$ i $300 \mathrm{~K}, K s=4,35 \pm 0,43 \mathrm{~W} \mathrm{~m}^{-1} \mathrm{~K}^{-1}$ oraz $P=0,101 \pm 0,007$ (Szurgot, 2019) prowadzi dla chondrytu Jezersko do wartości $K(300 \mathrm{~K}, 1 \mathrm{~atm})=2,59 \pm 0,28 \mathrm{~W} \mathrm{~m}^{-1} \mathrm{~K}^{-1}$ $\approx 2,6 \pm 0,3 \mathrm{~W} \mathrm{~m}^{-1} \mathrm{~K}^{-1}$ (tab. 2, rys. 1 i 2 ).

Przyjęcie dla warunków niskiego ciśnienia $\left(10^{-5} \mathrm{~Pa}\right) /$ próżni wartości przewodności cieplnej bardzo rozrzedzonego powietrza $K f\left(10^{-5} \mathrm{~Pa}\right)=0,000003 \mathrm{~W} \mathrm{~m}^{-1} \mathrm{~K}^{-1}$ (Soini et al., 2020) 
prowadzi w przypadku meteorytu Jezersko do wartości przewodności cieplnej w temperaturze $300 \mathrm{~K}: 1,04 \pm 0,11 \mathrm{~W} \mathrm{~m}^{-1}$ $\mathrm{K}^{-1} \approx 1,0 \pm 0,1 \mathrm{~W} \mathrm{~m}^{-1} \mathrm{~K}^{-1}$ (tab. 2, rys. 1 i 2 ).

Zbliżoną wartość efektywnej przewodności cieplnej skały w warunkach próżni, oznaczonej jako $(K v)$ chondrytu Jezersko otrzymano, wykorzystując równanie Walsha i Deckera (1966), które dla bardzo niskiego ciśnienia (wysokiej próżni) i niskich temperatur ma postać:

$$
(K s-K v) / K s=2 P /(3 \Pi \alpha)
$$

gdzie: $K s$ to przewodność cieplna składników stałych, $P$ to porowatość skały, natomiast $\alpha$ to współczynnik kształtu porów (Walsh i Decker, 1966; Soini et al., 2020). Przekształcając to równanie, otrzymujemy zależność:

$$
K v=K s \cdot(1-2 P /(3 \Pi \alpha))
$$

Podstawienie do równania (7) wartości: $K s=4,35 \pm 0,43$ $\mathrm{W} \mathrm{m}{ }^{-1} \mathrm{~K}^{-1}, P=0,101 \pm 0,07$ (Szurgot, 2019) oraz $\alpha=0,028$, obliczonej z zależności $\alpha(P)$ wyznaczonej przez Soini i in. (2020), prowadzi do otrzymania przewodności cieplnej chondrytu Jezersko w warunkach próżni wynoszącej $1,02 \pm 0,24 \mathrm{~W} \mathrm{~m}^{-1} \mathrm{~K}^{-1}$, prawie identycznej jak uzyskana z modelu średniej geometrycznej (równanie (5)) (tab. 2).

Wyniki obliczeń wykorzystujących równanie (5) wskazują, że powietrze obecne w porach pod ciśnieniem 1 atm zmniejsza przewodność cieplną meteorytu Jezersko do wartości 0,59 Ks, a powietrze rozrzedzone $\left(10^{-5} \mathrm{~Pa}\right)$ redukuje przewodność cieplną chondrytu Jezersko w jeszcze większym stopniu, do wartości 0,29 Ks przewodności cieplnej jej składników mineralnych.

Wzory (2)-(5) modelu średniej geometrycznej reprezentują sytuację dla homogenicznego i izotropowego ośrodka skalnego, równomiernego przestrzennego rozłożenia składników mineralnych oraz porów w skale. W badaniach termofizycznych do opisu przewodności cieplnej stosujemy różne modele skał, zwykle modele warstwowe, modele inkluzyjne oraz modele mieszane. Modele warstwowe skał: model średniej arytmetycznej i model średniej harmonicznej reprezentują przypadki warstwowego/laminarnego ułożenia składników skały. Skała w modelach warstwowych jest reprezentowana przez warstwy stanowiące poszczególne składniki skały, a względna grubość warstw $(Z i)$ przedstawia udział objętości danego składnika w skale (Vi). Model średniej arytmetycznej / model „równoległy” opisuje sytuację, gdy strumień ciepła płynie równolegle do granic między składnikami, a model średniej harmonicznej / model „prostopadły” - gdy strumień ciepła płynie prostopadle do granic między składnikami (warstwami) skały (Schön, 2011).

Według modelu średniej harmonicznej przewodność cieplną szkieletu skały $(K s)$ lub/i całej skały meteorytu $(K)$ można wyznaczyć z zależności:

Tabela 1. Przewodność cieplna minerałów składowych meteorytu $(K i)$, objętość minerałów $(V i)$ w szkielecie i w całej skale chondrytu Jezersko, przewodność cieplna szkieletu skalnego $(K s)$ chondrytu oraz powietrza w porach $(K f)$ w temperaturze $300 \mathrm{~K}$ i ciśnieniu $1 \mathrm{~atm}$

Table 1. Thermal conductivity of constituent minerals $(\mathrm{Ki})$, their volume $(\mathrm{Vi})$ in the matrix and the whole rock, and of the matrix of the Jezersko chondrite $(K s)$, and the thermal conductivity of the matrix and of air in the pores $(K f)$ at $300 \mathrm{~K}$ for

\begin{tabular}{|c|c|c|c|}
\hline \multirow[t]{2}{*}{ Mineral/Szkielet skalny } & \multirow{2}{*}{$\begin{array}{c}K i / K s \\
{\left[\mathbf{W} \mathbf{m}^{-1} \mathbf{K}^{-1}\right]}\end{array}$} & \multicolumn{2}{|c|}{$\begin{array}{c}\text { Vi } \\
{[\% \text { obj./vol. \%] }}\end{array}$} \\
\hline & & w szkielecie skaly & w całej skale \\
\hline Oliwin & $4,3^{\mathrm{a}}$ & 32 & \multirow{6}{*}{89,9} \\
\hline Ortopiroksen & $3,9^{\mathrm{a}}$ & 32,4 & \\
\hline Klinopiroksen & $4,6^{\mathrm{a}}$ & 9,2 & \\
\hline Plagioklaz & $1,9^{\mathrm{a}}$ & 13,6 & \\
\hline Troilit & $4,6^{\mathrm{a}, \mathrm{c}}$ & 3,2 & \\
\hline Fe-Ni Metal & $28,1^{\mathrm{b}}$ & 8,6 & \\
\hline Powietrze & 0,026 & & 10,1 \\
\hline Szkielet skalny $K s$-geom ${ }^{*}$ & $4,35 \pm 0,43$ & & \multirow{2}{*}{89,9} \\
\hline Szkielet skalny $(K s$-arithm $+K s$-harm $) / 2^{*}$ & $4,9 \pm 1,4$ & & \\
\hline
\end{tabular}
pressure at $1 \mathrm{~atm}$

a (Yomogida i Matsui, 1983)

b (Ho et al., 1978)

c (Clauser i Huenges, 1995)

* Ks-geom, Ks-arithm oraz Ks-harm to wartości przewodności cieplnej (TC) szkieletu skalnego (Ks) obliczone za pomocą modelu: średniej geometrycznej (Ks-geom), średniej arytmetycznej (Ks-arithm) oraz średniej harmonicznej (Ks-harm) z wykorzystaniem danych o wartościach $K i$ oraz $V i$ minerałów budujących skałę chondrytu Jezersko

"Ks-geom, Ks-arithm and Ks-harm are values of thermal conductivity (TC) of matrix (Ks) calculated by mean geometric model (Ks-geom), arithmetic mean model (Ks-arithm), and harmonic mean model (Ks-harm) using $K i$ and $V i$ values for Jezersko constituent minerals 
Tabela 2. Przewodność cieplna całej skały chondrytu Jezersko w $300 \mathrm{~K}, 200 \mathrm{~K}$ i 200-300 K

Table 2. Thermal conductivity of the whole rock of the Jezersko chondrite at $300 \mathrm{~K}, 200 \mathrm{~K}$, and $200-300 \mathrm{~K}$

\begin{tabular}{|c|c|c|c|}
\hline \multirow{2}{*}{$\begin{array}{c}\text { K (model) } \\
\text { K (właściwość fizyczna) }\end{array}$} & \multirow{2}{*}{ Równanie } & \multicolumn{2}{|c|}{$\begin{array}{c}\text { Przewodność cieplna } K \\
{\left[\mathbf{W} \mathbf{m}^{-1} \mathbf{K}^{-1}\right]}\end{array}$} \\
\hline & & $\begin{array}{c}\text { Powietrze } \\
10^{5} \mathrm{~Pa}\end{array}$ & $\begin{array}{c}\text { Próżnia } \\
10^{-5} \mathrm{~Pa}\end{array}$ \\
\hline$($ Karithm + Kharm $) / 2^{*}$ & $(8),(9)$ & $2,07\{0,24-3,91\}$ & $1,96\{0,00003-3,91\}$ \\
\hline$(\mathrm{KCM}-+\mathrm{KCM}+) / 2^{*}$ & & $2,17\{0,62-3,73\}$ & $1,86\{0,0001-3,72\}$ \\
\hline$(\mathrm{KHS}-+\mathrm{KHS}+) / 2^{*}$ & & $2,38\{0,75-4,01\}$ & $1,86\{0,0001-3,72\}$ \\
\hline Kgeom (Compos., P) ${ }^{*}$ & (2), (5) & $2,59 \pm 0,28$ & $1,04 \pm 0,11$ \\
\hline $\mathrm{K}($ arith + harm $) / 2(\text { Compos., } \mathrm{P})^{\#}$ & $(2),(5)$ & $2,89 \pm 0,74$ & $1,95 \pm 0,32$ \\
\hline $\mathrm{K}($ model $)$ - średnia & & $2,42 \pm 0,33(5)$ & $1,73 \pm 0,39(5)$ \\
\hline \multirow{4}{*}{$\mathrm{K}(\mathrm{P})$} & (7) & & $1,02 \pm 0,24 \mathrm{WD}^{* *}$ \\
\hline & $(11)$ & & $1,03 \pm 0,05 \mathrm{Op}^{* *}$ \\
\hline & $(11)$ & & $1,20 \pm 0,07 \mathrm{~F}^{* *}$ \\
\hline & $(10)$ & & $1,49 \pm 0,10 \mathrm{~S}^{* *}$ \\
\hline $\mathrm{K}(\mathrm{P})$ - średnia & & & $1,18 \pm 0,22(4)$ \\
\hline \multirow{3}{*}{$\mathrm{K}(\mathrm{D})$} & (12) & $2,57 \pm 0,73 \mathrm{SW}^{* * *}$ & $0,95 \pm 0,52 \mathrm{SW}+\mathrm{O}^{* *}$ \\
\hline & (12) & & $1,16 \pm 0,12 \mathrm{~S}^{* *}$ \\
\hline & $(12)$ & & $1,26 \mathrm{SW}+\mathrm{O}^{* *}$ \\
\hline $\mathrm{K}(\mathrm{D})$ - średnia & & & $1,12 \pm 0,16(3)$ \\
\hline Zakres K & & $2,0-2,9$ & $0,95-2,0$ \\
\hline Średnia K & & $2,45 \pm 0,30(6)$ & $1,40 \pm 0,40(12)$ \\
\hline
\end{tabular}

* Obliczono, stosując przewodność cieplną szkieletu skały: $4,35 \mathrm{~W} \mathrm{~m}^{-1} \mathrm{~K}^{-1} \mathrm{w} 300 \mathrm{~K}$ oraz przewodność cieplną powietrza $K f=0,026 \mathrm{~W} \mathrm{~m}{ }^{-1} \mathrm{~K}^{-1} \mathrm{dla} 1 \mathrm{~atm}$ i $K f=0,000003 \mathrm{~W} \mathrm{~m}^{-1} \mathrm{~K}^{-1}$ dla próżni $\left(10^{-5} \mathrm{~Pa}\right)$ \{Granica dolna $\div$ Granica górna\}

* Calculated using the thermal conductivity of the matrix: $4.35 \mathrm{~W} \mathrm{~m}^{-1} \mathrm{~K}^{-1}$ at $300 \mathrm{~K}$ and the thermal conductivity of air $K f=0.026 \mathrm{~W} \mathrm{~m} \mathrm{~K}^{-1}$ for 1 atm, and $K f=0.000003 \mathrm{~W} \mathrm{~m}^{-1} \mathrm{~K}^{-1}$ in vacuum $\left(10^{-5} \mathrm{~Pa}\right)$ \{Lower limit $\div$ Upper limit

\# Obliczono, stosując przewodność cieplną szkieletu skały: 4,9 W m ${ }^{-1} \mathrm{~K}^{-1} \mathrm{w} 300 \mathrm{~K}$

${ }^{*}$ Calculated using the thermal conductivity of the matrix: $4.9 \mathrm{~W} \mathrm{~m}^{-1} \mathrm{~K}^{-1}$ at $300 \mathrm{~K}$

${ }^{* *} S$ - (Soini et al., 2020), SW - (Szurgot i Wojtatowicz, 2011), SW + O - (Szurgot i Wojtatowicz, 2011 + Osako, 1981); WD - (Walsh i Decker, 1966), F - (Flynn et al., 2018), Op - (Opeil et al., 2006, 2012); (Liczba przewidywań)/(Number of predictions).

$$
K=(\Sigma Z \mathrm{i} / K i)^{-1}=(\Sigma \mathrm{Vi} / K i)^{-1}
$$

a według modelu średniej arytmetycznej z zależności:

$$
K=\Sigma Z i \cdot K i=\Sigma V i \cdot K i
$$

gdzie: $Z i$ to szerokość $i$-tej warstwy skały, $i=1, \ldots, \mathrm{n}-$ dla $n$ składników szkieletu skały, $i=1,2-$ dla całej skały $(K)$ traktowanej jako układ dwuskładnikowy: szkielet ziarnowy i pory. Przy założeniu, że $i$-tą warstwę stanowi jeden minerał, do obliczeń można wykorzystać objętości $V i$ zamiast szerokości $Z i$, ponieważ $V \mathbf{i} \sim Z i$ przy założeniu tej samej powierzchni, przez którą przepływa ciepło.

Wartość przewodności cieplnej szkieletu ziarnowego $K s$ meteorytu Jezersko według modelu średniej harmonicznej (równanie (8)) dla przepływu ciepła zachodzącego prostopadle do warstw, tj. do sześciu warstw złożonych z poszczególnych minerałów budujących skałę chondrytu, wynosi $3,9 \mathrm{~W} \mathrm{~m}^{-1} \mathrm{~K}^{-1}$, a według modelu średniej arytmetycznej (równanie (9)) dla przepływu ciepła zachodzącego równolegle do warstw wynosi 5,9 $\mathrm{W} \mathrm{m}^{-1} \mathrm{~K}^{-1}$.
Model średniej harmonicznej określa dolną granicę przewodności cieplnej skały, a model średniej arytmetycznej - jej górną granicę. Średnia arytmetyczna z obu tych granic przewodności cieplnej szkieletu ziarnowego chondrytu Jezersko wynosi $4,9 \pm 1,4 \mathrm{~W} \mathrm{~m}^{-1} \mathrm{~K}^{-1}$ (tab. 1). Wartość ta jest nieco większa, ale dość bliska wartości Ks wynikającej z modelu średniej geometrycznej, uznawanej za dobrze reprezentującą eksperymentalne wartości przewodności cieplnej skał ziemskich (Schön, 2011; Przelaskowska, 2018). Oznacza to, że także średnia arytmetyczna z przewodności cieplnych wynikających z dwóch skrajnych przypadków warstwowego ułożenia składników reprezentuje przewodność cieplną szkieletu ziarnowego skały.

Zastosowanie modelu średniej harmonicznej i modelu średniej arytmetycznej do oszacowania przewodności cieplnej całej skały chondrytu Jezersko, przyjmując model dwuskładnikowy: szkielet ziarnowy oraz pory wypełnione powietrzem $(i=1,2)$, przewiduje wartości: $0,24 \mathrm{~W} \mathrm{~m}^{-1} \mathrm{~K}^{-1}$ i $3,91 \mathrm{~W} \mathrm{~m}^{-1} \mathrm{~K}^{-1}$ dla powietrza pod ciśnieniem $1 \mathrm{~atm}$ oraz wartości $0,00003 \mathrm{~W} \mathrm{~m}^{-1} \mathrm{~K}^{-1}$ i 3,91 $\mathrm{W} \mathrm{m}^{-1} \mathrm{~K}^{-1}$ dla warunków próżni (powietrze pod ciśnieniem $10^{-5} \mathrm{~Pa}$ ). 
Rys. 1. Przykłady zależności pomiędzy przewodnością cieplną chondrytów a ich porowatością $K(P)$ wyrażone przez różne funkcje. Równanie (5) wyraża zależność potęgową według modelu średniej geometrycznej dla powietrza pod ciśnieniem 1 atm oraz dla próżni. Równanie (10) prezentuje zależność liniową otrzymaną dla wspólnych danych Soini i in. oraz innych danych literaturowych dotyczących pomiarów przewodności cieplnej chondrytów w próżni (Soini et al., 2020), a równanie (11) opisuje zależność hiperboliczną uzyskaną dla pomiarów $K$ chondrytów w warunkach próżni przez Opeila i in. (2012) dla wspólnych danych eksperymentalnych tych badaczy oraz danych Matsui i Osako (1983). Wartości $K$ przewidywane dla chondrytu Jezersko są prezentowane jako punkty zależności $K(P)$ dla wartości porowatości $P=0,101=10,1 \%$ oraz jako punkty przewidywań z wykorzystaniem różnych modeli opisanych w tekście pracy oraz w tabeli 2. Wyniki ujawniają dwa zgrupowania wartości $K$ przewidywanych dla meteorytu Jezersko. Wyższe wartości $K$ uzyskuje się, gdy ośrodkiem wypełniającym pory skały chondrytu jest powietrze, a niższe wartości $K$, gdy pory są wypełnione bardzo rozrzedzonym powietrzem pod ciśnieniem $10^{-5}-0,1$ Pa (próżnia). Prezentowane dane przewodności cieplnej dotyczą zakresu temperatur 200-300 K

Fig. 1. Relationships between porosity and thermal conductivity $K(P)$ expressed by different functions. The equation (5) presents a power function given by the geometric mean model between the thermal conductivity of chondrites and porosity for air at 1 atm, and in vacuum. The equation (10) is a linear $K(P)$ relationship established by Soini et al. (2020) in vacuum, using joint literature and Soini et al. experimental data (2020). The equation (11) presents hyperbolic $K(P)$ function established by Opeil et al. (2012) based on measurements of the thermal conductivity of chondrites in vacuum, and on experimental data measured by Matsui and Osako (1983). $K$ values predicted for the Jezersko chondrite are presented by points on $K(P)$ curves for porosity $P=0.101=10.1 \%$, and by points predicted by various models of rocks used in this paper. All $K$ values calculated for the Jezersko chondrite $\mathrm{K}$ are compiled in Table 2. Two groups of $K$ values for the Jezersko chondrite can be noticed. Higher $K$ values are obtained for the first group for air at ambient conditions, and the second group presents lower $K$ values predicted in vacuum, i.e. for very low pressure of air in pores $\left(10^{-5}-0.1 \mathrm{~Pa}\right)$. The presented $K$ data concern the temperature range $200-300 \mathrm{~K}$

Rys. 2. Zestawienie wartości przewodności cieplnej $K$ meteorytu Jezersko przewidywanych z wykorzystaniem różnych modeli skał: modelu średniej arytmetycznej (Arithm), modelu średniej harmonicznej (Harm), modelu średniej geometrycznej (Kgeom), modelu Hashina-Shtrikmana (HS), modelu Clausiusa-Mossottiego (CM) i różnych zależności eksperymentalnych pomiędzy przewodnością cieplną i porowatością $K(P)$ oraz pomiędzy przewodnością cieplną i dyfuzyjnością cieplną $K(D)$. Przewidywania dotyczące wartości $K$, gdy ośrodkiem wypełniającym pory jest powietrze, oznaczono kolorem czerwonym, natomiast kolorem niebieskim wyróżniono przewidywania dla próżni. Zielone kwadraty prezentują globalne średnie wartości $K$ dla chondrytu Jezersko wyznaczone ze wszystkich przewidywań. Dla porównania prezentowane są eksperymentalne wartości przewodności cieplnej dwóch chondrytów należących do tej samej grupy H: chondrytu Pułtusk (Opeil et al., 2012) oraz chondrytu Metsäkylä (Soini et al., 2020). Wartości przewodności cieplnej meteorytu Jezersko określone w niniejszej pracy są prezentowane w tabelach 2 i 3, wartości $K$ minerałów składowych meteorytu Jezersko w tabeli 1, a wartości $K$ chondrytów grupy H w tabeli 3. Na rysunku pokazano także wartość przewodności cieplnej szkieletu skalnego meteorytu Jezersko $(K s)$ i przewodności cieplnej powietrza wypełniającego pory $(K f)$. I te wyniki uwidaczniają dwa zgrupowania wartości $K$ przewidywanych dla meteorytu Jezersko: wyższe wartości $K$ dla powietrza, a niższe $K$ wyznaczone dla próżni

Fig. 2. Values of thermal conductivity $K$ predicted for the Jezersko chondrite by various models of rocks: arithmetic and harmonic mean models, the geometric mean model, the Hashin-Shtrikman $(H S)$ model, the Clausius-Mossotti model $(C M)$, and various dependencies: between $K$ and porosity $K(P)$, and between $K$ and thermal diffusivity $K(D)$. $K$ values presented in red are for air, and those presented in blue are in vacuum. Green squares denote the global mean resulting from all predictions. For comparison with the Jezersko meteorite predicted $K$ values, $K$ experimental data established for two ordinary chondrites belonging to the same H group: Pultusk (Opeil et al., 2012), and Metsäkylä (Soini et al., 2020) are presented. Detailed values of thermal conductivity of the Jezersko chondrite and its minerals are collected in Tables 1, 2, 3, and $K$ values for selected $H$ chondrites in Table 3 . The thermal conductivity of the skeleton/matrix $K s$ of the Jezersko chondrite and $K$ of fluid $K f$ present in pores are also presented in this diagram. Two groups of $K$ values for the Jezersko chondrite are also present in this diagram: higher $K$ values are characteristic of air at $1 \mathrm{~atm}$, and lower $\mathrm{K}$ values are predicted in vacuum 
Daje to uśrednioną wartość przewodności cieplnej całej skały chondrytu Jezersko: $2,07 \mathrm{~W} \mathrm{~m}^{-1} \mathrm{~K}^{-1}$ dla ciśnienia $1 \mathrm{~atm}$ oraz $1,96 \mathrm{~W} \mathrm{~m}^{-1} \mathrm{~K}^{-1}$ dla ciśnienia $10^{-5} \mathrm{~Pa}$ (tab. 2, rys. 2).

Do analizy wartości przewodności cieplnej chondrytu Jezersko wykorzystano również model Hashina-Shtrikmana (HS), zakładający makroskopową jednorodność (homogeniczność) i izotropowość ośrodka. Równania Hashina-Shtrikmana określają granice, pomiędzy którymi znajduje się rzeczywista wartość przewodności cieplnej skały lub innego, złożonego ośrodka (Hashin i Shtrikman, 1962). Dolna granica (HS-) reprezentuje geometrię skały, w której sferyczne ziarna minerałów budujących skałę są rozproszone w ośrodku porowym, a górna granica (HS+) dotyczy struktury skały, w której ośrodek porowy ograniczony jest do sferycznych inkluzji w szkielecie ziarnowym (Hashin i Shtrikman, 1962; Przelaskowska, 2018).

Obliczenia pokazują, że w przypadku powietrza wypełniającego pory dla ciśnienia $1 \mathrm{~atm}$ dolna granica $K_{H S-}$ przewidywana dla wartości przewodności cieplnej meteorytu Jezersko, na podstawie wyznaczonej wcześniej z modelu średniej geometrycznej wartości $K s=4,35 \mathrm{~W} \mathrm{~m}^{-1} \mathrm{~K}^{-1}$, wynosi $0,75 \mathrm{~W} \mathrm{~m}^{-1} \mathrm{~K}^{-1}$, a górna granica $K_{H S+}$ wynosi $4,01 \mathrm{~W} \mathrm{~m}^{-1} \mathrm{~K}^{-1}$. Średnia arytmetyczna $\mathrm{z}$ tych dwóch granic HS jest równa $2,38 \mathrm{~W} \mathrm{~m}^{-1} \mathrm{~K}^{-1} \approx$ $2,4 \mathrm{~W} \mathrm{~m}^{-1} \mathrm{~K}^{-1}$. Gdy pory są wypełnione bardzo rozrzedzonym powietrzem (próżnia $10^{-5} \mathrm{~Pa}$ ), model HS przewiduje dla całej skały chondrytu Jezersko zakres wartości: 0,0001$3,72 \mathrm{~W} \mathrm{~m}^{-1} \mathrm{~K}^{-1}$ oraz wartość średnią $K_{H S}=1,86 \mathrm{~W} \mathrm{~m}^{-1} \mathrm{~K}^{-1} \approx$ $1,9 \mathrm{~W} \mathrm{~m}^{-1} \mathrm{~K}^{-1}$. Oznacza to, że wartość przewodności cieplnej chondrytu Jezersko wynikająca z modelu średniej geometrycznej jest porównywalna, ale nieco wyższa $\left(2,6 \mathrm{~W} \mathrm{~m}^{-1} \mathrm{~K}^{-1}\right)$ niż wartość wynikająca z modelu HS dla porów wypełnionych powietrzem pod ciśnieniem 1 atm, natomiast dla warunków próżni $\left(10^{-5} \mathrm{~Pa}\right)$ model średniej geometrycznej przewiduje znacznie niższą wartość przewodności cieplnej chondrytu Jezersko $\left(1,0 \mathrm{~W} \mathrm{~m}^{-1} \mathrm{~K}^{-1}\right)$ niż model HS. Tabela 2 oraz rysunki 1 i 2 prezentują wartości przewodności cieplnej chondrytu Jezersko przewidywane przez różne modele skał, a także przez zależności $K(P)$ oraz $K(D)$.

Do analizy wartości przewodności cieplnej chondrytu Jezersko wykorzystano także jeden z modeli inkluzyjnych - model inkluzji sferycznych Clausiusa-Mossottiego (CM) (Schön, 2011; Przelaskowska, 2018). W modelu tym są rozpatrywane dwa graniczne przypadki: (i) skała, której składnikiem podstawowym jest szkielet ziarnowy, a płyny porowe występują w postaci sferycznych inkluzji (model analogiczny do górnej granicy $\mathrm{H}-\mathrm{S}$ ), oraz (ii) skała złożona ze sferycznych ziaren rozproszonych w płynie porowym. Wartości przewodności cieplnej całej skały dla tych dwu przypadków oznaczono odpowiednio: $K_{\mathrm{CM}^{+}}$oraz $K_{\mathrm{CM}-\text {. }}$

Obliczenia oparte na wyrażeniach opisujących przewodność cieplną skał w tym modelu (Schön, 2011; Przelaskowska, 2018) pokazują, że w przypadku powietrza wypełniającego pory dla ciśnienia 1 atm dolna granica $K_{C M}$ przewidywana dla wartości przewodności cieplnej meteorytu Jezersko, w oparciu o wyznaczoną wcześniej z modelu średniej geometrycznej wartość $K s=4,35 \mathrm{~W} \mathrm{~m}^{-1} \mathrm{~K}^{-1}$, wynosi $0,62 \mathrm{~W} \mathrm{~m}^{-1} \mathrm{~K}^{-1}$, a górna granica $K_{C M^{+}}$wynosi $3,73 \mathrm{~W} \mathrm{~m}^{-1} \mathrm{~K}^{-1}$. Średnia arytmetyczna z tych dwóch granic CM jest równa $2,18 \mathrm{~W} \mathrm{~m}^{-1} \mathrm{~K}^{-1} \approx 2,2 \mathrm{~W} \mathrm{~m}^{-1} \mathrm{~K}^{-1}$. Gdy pory są wypełnione rozrzedzonym powietrzem (próżnia $10^{-5} \mathrm{~Pa}$ ), model CM przewiduje dla całej skały chondrytu Jezersko zakres wartości: $0,0001-3,72 \mathrm{~W} \mathrm{~m}^{-1} \mathrm{~K}^{-1}$ oraz wartość średnią $K_{C M}=1,86 \mathrm{~W} \mathrm{~m}^{-1} \mathrm{~K}^{-1} \approx 1,9 \mathrm{~W} \mathrm{~m}^{-1} \mathrm{~K}^{-1}$. Ta wartość średnia przewodności cieplnej chondrytu Jezersko, wynikająca z modelu Clausiusa-Mossottiego, jest nieco niższa niż wartość wynikająca z modelu HS dla porów wypełnionych powietrzem pod ciśnieniem 1 atm $\left(2,6 \mathrm{~W} \mathrm{~m}^{-1} \mathrm{~K}^{-1}\right)$, natomiast dla warunków próżni $\left(10^{-5} \mathrm{~Pa}\right)$ model średniej geometrycznej przewiduje znacznie niższą wartość przewodności cieplnej chondrytu Jezersko (1,0 W m ${ }^{-1} \mathrm{~K}^{-1}$ ) niż oba modele: CM oraz HS (tab. 2, rys. 2).

Niżej zaprezentowano zależności empiryczne i przewidywania z nich wynikające dla materii pozaziemskiej wiążące przewodność cieplną z porowatością. Jak wiadomo, porowatość materiału odgrywa w transporcie ciepła istotną rolę. Wpływ porowatości i rodzaju fluidu wypełniającego pory na przewodność cieplną skał ziemskich i pozaziemskich jest wyraźny (równania (2), (5), (7)). Skały o większej porowatości wykazują mniejszą przewodność cieplną niż skały o mniejszej porowatości (Griffiths et al., 1992; Szewczyk, 2001; Schön, 2011; Przelaskowska, 2018). Zależność $K(P)$ przewodności cieplnej $K$ od porowatości $P$ meteorytów kamiennych, także chondrytów, może być wyrażona przez różne funkcje: liniową, hiperboliczną i wykładniczą.

Według Soini i in. (2020) zależność $K(P)$ dla spadków chondrytów może być opisana funkcją liniową:

$$
K=a \cdot P+b
$$

gdzie: stałe $a$ oraz $b$ według pomiarów Soini i in. (2020) są równe: $a=-0,1457, b=2,9614$ dla własnych danych eksperymentalnych autorów oraz $a=-0,1536, b=2,816$ dla wspólnych danych literaturowych i własnych. Porowatość $P$ jest wyrażona w $[\%]$, a $K \mathrm{w}\left[\mathrm{W} \mathrm{m}^{-1} \mathrm{~K}^{-1}\right]$ dla temperatury pokojowej ( $\left.300 \mathrm{~K}, 10^{-4} \mathrm{~Pa}\right)$. Wykorzystanie tej aproksymacji prowadzi do następujących wartości $K(300 \mathrm{~K})$ dla chondrytu Jezersko: $1,49 \pm 0,10 \mathrm{~W} \mathrm{~m}^{-1} \mathrm{~K}^{-1}$ dla pomiarów Soini i in. (2020) oraz do wartości $K(200-300 \mathrm{~K}$, $\left.10^{-4}-10^{-1} \mathrm{~Pa}\right)=1,28 \pm 0,10 \mathrm{~W} \mathrm{~m}^{-1} \mathrm{~K}^{-1}$ dla wspólnych danych różnych autorów (Soini et al., 2020).

Nieliniową, hiperboliczną zależność $K(P)$ zaobserwowało kilku badaczy. Opeil i in. (2012) na podstawie danych własnych oraz danych Yomogidy i Matsuiego (1983) pokazali, że zależność ta ma postać: 


$$
K\left(200 \mathrm{~K}, 10^{-4} \mathrm{~Pa}-0,1 \mathrm{~Pa}\right)=e \cdot(1 / P)+f
$$

gdzie: $P$ - to porowatość meteorytu. Współczynniki tego równania wynoszą: $e=0,0678, f=0,356$ według wartości $K$ i $P$ zmierzonych przy ciśnieniu $10^{-4} \mathrm{~Pa}$ przez Opeila i in. (2012). Uwzględnienie także danych Yomogidy i Matsuiego (1983) dla ciśnienia 0,1 Pa nieco zmienia te współczynniki - i wynoszą one: $e=0,0690, f=0,382\left(R^{2}=0,81\right)$. Według analizy Flynna $i$ in. (2018) obejmującej także dane Opeila i in. (2012) oraz Yomogidy i Matsuiego (1983) współczynniki e i $f$ równania (11) wynoszą: $e=0,0690, f=0,253\left(R^{2}=0,66\right)$. Podstawienie wartości $P=0,101 \pm 0,07$ dla chondrytu Jezersko do równania (11) prowadzi według aproksymacji Opeila i in. (2012) do następujących wartości przewodności cieplnej w temperaturze $200 \mathrm{~K}$ : $1,03 \pm 0,05 \mathrm{~W} \mathrm{~m}^{-1} \mathrm{~K}^{-1} \mathrm{dla} 10^{-4} \mathrm{~Pa}$, a $1,06 \pm 0,05 \mathrm{~W} \mathrm{~m}^{-1} \mathrm{~K}^{-1}$ dla ciśnienia $10^{-4}-0,1 \mathrm{~Pa}$, natomiast do wartości: $1,20 \pm 0,07$ $\mathrm{W} \mathrm{m}^{-1} \mathrm{~K}^{-1}$ według aproksymacji Flynna i in. (2018) dla tego samego zakresu ciśnień.

Wykresy zależności przewodności cieplnej od porowatości $(K(P))$ i przewidywane wartości $K$ dla chondrytu Jezersko z wykorzystaniem równań: (5), (10) i (11) oraz wartości $K$ wyznaczone z zastosowaniem różnych modeli skał są pokazane na rysunku 1. Wartości $K$ przewidywane dla chondrytu Jezersko są prezentowane jako punkty zależności $K(P)$ dla wartości porowatości $P=0,101=10,1 \%$ oraz jako punkty przewidywań $\mathrm{z}$ wykorzystaniem różnych modeli opisanych $\mathrm{w}$ tekście pracy i w tabeli 2 . Wyniki ujawniają dwa zgrupowania wartości $K$ przewidywanych dla meteorytu Jezersko. Wyższe wartości $K$ uzyskuje się, gdy ośrodkiem wypełniającym pory skały chondrytu jest powietrze, a niższe wartości $K$, gdy pory są wypełnione bardzo rozrzedzonym powietrzem pod ciśnieniem: $10^{-5}-0,1 \mathrm{~Pa}$ (próżnia). Rysunek 2, na którym zestawiono wartości przewodności cieplnej $K$ meteorytu Jezersko przewidywane z wykorzystaniem różnych modeli skał i różnych zależności eksperymentalnych pomiędzy przewodnością cieplną i porowatością $K(P)$ oraz pomiędzy przewodnością cieplną i dyfuzyjnością cieplną $K(D)$, również ujawnia te dwa zgrupowania wartości przewodności cieplnej meteorytu Jezersko.

Porowatość $P$ meteorytu występuje w wykładniku potęgi równań (2) i (5). Dla celów modelowania ewolucji cieplnej ciał macierzystych chondrytów Henke i in. (2016) wykorzystywali zależność potęgową $K(P)$, która dla porowatości chondrytu Jezersko przewiduje wartość przewodności cieplnej tego chondrytu wynoszącą $1,22 \pm 0,11 \mathrm{~W} \mathrm{~m}^{-1} \mathrm{~K}^{-1}$.

Właściwością rządzącą przepływem ciepła w stanie nieustalonym, gdy temperatura ciała i strumień cieplny zmieniają się w czasie, jest dyfuzyjność cieplna $D\left(\mathrm{~m}^{2} / \mathrm{s}\right)$, znana też jako współczynnik wyrównywania temperatury. Istnieje współzależność pomiędzy przewodnością cieplną i dyfuzyjnością cieplną:

$$
K(D)=D \cdot C \text { volumetric }
$$

gdzie: Cvolumetric to objętościowe ciepło właściwe, zdefiniowane jako iloczyn ciepła właściwego meteorytu pod stałym ciśnieniem i gęstości objętościowej. Ten związek także wykorzystano do przewidywania/weryfikacji globalnej przewodności cieplnej meteorytu Jezersko. Do obliczeń $K$ wykorzystano wartości Cvolumetric chondrytu Jezersko określone wcześniej przez autora (Szurgot, 2020a), natomiast przewidywania wartości dyfuzyjności cieplnej tego meteorytu oparto na zależności dyfuzyjności od gęstości objętościowej $D$ (dbulk) (Szurgot i Wojtatowicz, 2011) oraz na zależności dyfuzyjności cieplnej od porowatości $D(P)$ meteorytu (Soini et al., 2020). Zgodnie z zależnością $D($ dbulk) i danymi eksperymentalnymi Szurgota i Wojtatowicza (2011) wartość liczbowa dyfuzyjności cieplnej meteorytu Jezersko w temperaturze pokojowej $(300 \mathrm{~K})$ i dla ciśnienia atmosferycznego $1 \mathrm{~atm}$ wynosi: $1,11 \pm 0,25 \cdot 10^{-6} \mathrm{~m}^{2} / \mathrm{s}$, a zgodnie $\mathrm{z}$ danymi eksperymentalnymi Osako (1981) dla obniżonego ciśnienia (1 Pa) wynosi dla temperatury $300 \mathrm{~K}: 0,41 \pm 0,20 \cdot 10^{-6} \mathrm{~m}^{2} / \mathrm{s}$, a dla temperatury $200 \mathrm{~K}: 0,72 \pm 0,21 \cdot 10^{-6} \mathrm{~m}^{2} / \mathrm{s}$. Podstawienie tych wartości dyfuzyjności cieplnej oraz wartości objętościowego ciepła właściwego $2,32 \pm 0,12 \mathrm{MJ} /\left(\mathrm{m}^{3} \cdot \mathrm{kg}\right)$ dla $300 \mathrm{~K}$ oraz 1,75 $\pm 0,09 \mathrm{MJ} /\left(\mathrm{m}^{3} \cdot \mathrm{kg}\right.$ ) dla $200 \mathrm{~K}$ (Szurgot, 2020a) do równania (12) prowadzi do następujących wartości przewodności cieplnej meteorytu Jezersko w temperaturze $300 \mathrm{~K}$ : $2,58 \pm 0,71 \mathrm{~W} \mathrm{~m}^{-1} \mathrm{~K}^{-1}$ dla ciśnienia powietrza $1 \mathrm{~atm}$ oraz $0,95 \pm 0,51 \mathrm{~W} \mathrm{~m}^{-1} \mathrm{~K}^{-1}$ dla ciśnienia $1 \mathrm{~Pa}$, oraz do wartości $1,26 \pm 0,37 \mathrm{~W} \mathrm{~m}^{-1} \mathrm{~K}^{-1} \mathrm{~W}$ temperaturze $200 \mathrm{~K}$ dla ciśnienia $1 \mathrm{~Pa}$ (tab. 2, rys. 1 i 2 ).

Dane eksperymentalne o wartościach $K(200 \mathrm{~K})$ i $K(300 \mathrm{~K})$ otrzymane przez Opeila i in. (2012) oraz Yomogidę i Matsuiego (1983) dla wybranych chondrytów grupy H umożliwiają obliczenie stosunku $K(300 \mathrm{~K}) / K(200 \mathrm{~K})$ dla tych chondrytów: 0,96 dla La Ciénega (H6), 1,06 dla Pułtuska (H5), 1,08 dla Barbotana (H5), 1,12 dla Collescipoli (H5), 0,97 dla Monroe (H4), 1,06 dla Gladstone'a (H5) oraz 1,04 dla Cronstada. Daje to średnią: $K(300 \mathrm{~K}) / K(200 \mathrm{~K})=1,04 \pm 0,06$ dla całej grupy $\mathrm{H}$ oraz zakres wartości tego stosunku: 0,96-1,12 dla tej grupy. Oznacza to, że dla grupy $\mathrm{H}$ i chondrytu $\mathrm{H} 4$ Jezersko wartości $K$ dla obu temperatur $200 \mathrm{~K}$ i $300 \mathrm{~K}$ są - lub powinny być - bliskie jedna drugiej, a czynnikami decydującymi o przewodności cieplnej są: skład mineralny, porowatość oraz ciśnienie i rodzaj fluidu wypełniającego pory skał. Średnie wartości przewodności cieplnej dla meteorytu Jezersko przewidywane w niniejszej pracy dla przedziału temperatur 200-300 K można, zgodnie $\mathrm{z}$ danymi zamieszczonymi $\mathrm{w}$ tabeli 2 , uszeregować według następującej nierówności:

$K(P$, vacuum $)(1,18) \leq K(D$, vacuum $)(1,23)<K($ all models, vacuum $)(1,73)<K$ (all models, air $1 \mathrm{~atm})(2,42)$

$<K(D$, air $1 \mathrm{~atm})(2,57)$ 
gdzie wartości $K$ podane w nawiasach są wyrażone $\mathrm{w} \mathrm{W} \mathrm{m} \mathrm{m}^{-1} \mathrm{~K}^{-1}$. Zależność ta potwierdza znaczny wzrost przewodności cieplnej chondrytu Jezersko przy przejściu od warunków próżni do warunków normalnych dla ciśnienia powietrza $1 \mathrm{~atm}$.

W jednej z nowszych prac poświęconych modelowaniu ciała macierzystego chondrytów grupy $\mathrm{H}$ otrzymano rezultaty wskazujące, że przewodność cieplna ciała macierzystego chondrytów grupy $\mathrm{H}$ wynosi $1,75 \mathrm{~W} /(\mathrm{m} \cdot \mathrm{K})$ dla temperatury powierzchniowej planetoidy 6 Hebe: $178 \mathrm{~K}$ i zmienia się z porowatością (Henke et al., 2012). W innych modelach przyjmowano różne wartości $K$ z zakresu $1-5 \mathrm{~W} /(\mathrm{m} \cdot \mathrm{K})$ i różne temperatury powierzchniowe: $170-300 \mathrm{~K}$ (Henke et al., 2012; oraz prace tam cytowane). Przewidywane wartości przewodności cieplnej chondrytu Jezersko mieszczą się w zakresie przewodności cieplnej wskazywanej przez wyniki modelowania ciała macierzystego chondrytów $\mathrm{H}$ oraz dane eksperymentalne dla wybranych chondrytów grupy $\mathrm{H}$, oraz podgrupy $\mathrm{H} 4$ (tab. 3, rys. 2).

\section{Podsumowanie i wnioski}

Wyniki potwierdzają znane prawidłowości odnoszące się do skał ziemskich i meteorytów, że współczynnik porowatości skały i materia wypełniająca pory wpływają silnie na przewodność cieplną.

Model średniej geometrycznej przewiduje dla szkieletu ziarnowego meteorytu Jezersko wartość przewodności cieplnej 4,35 $\mathrm{W} \mathrm{m}^{-1} \mathrm{~K}^{-1}$, a średnia $\mathrm{z}$ dwóch modeli warstwowych: modelu średniej harmonicznej i modelu średniej arytmetycznej - wartość $4,9 \mathrm{~W} \mathrm{~m}^{-1} \mathrm{~K}^{-1}$ dla temperatury $300 \mathrm{~K}$. Globalna przewodność cieplna meteorytu Jezersko według modelu średniej geometrycznej w temperaturze $300 \mathrm{~K}$ wynosi: $2,6 \mathrm{~W} \mathrm{~m}^{-1} \mathrm{~K}^{-1}$ dla ciśnienia powietrza $1 \mathrm{~atm}$, a $1,0 \mathrm{~W} \mathrm{~m} \mathrm{~K}^{-1}$ dla próżni. Model Hashina-Shtrikmana przewiduje wartości $K$ wynoszące $2,4 \mathrm{~W} \mathrm{~m}^{-1} \mathrm{~K}^{-1} \mathrm{i} 1,9 \mathrm{~W} \mathrm{~m}^{-1} \mathrm{~K}^{-1}$, model ClausiusaMossottiego - wartości: $2,2 \mathrm{~W} \mathrm{~m}^{-1} \mathrm{~K}^{-1} \mathrm{i} 1,9 \mathrm{~W} \mathrm{~m}^{-1} \mathrm{~K}^{-1}$, a modele warstwowe wartości: $2,1 \mathrm{~W} \mathrm{~m}^{-1} \mathrm{~K}^{-1}$ i $2,0 \mathrm{~W} \mathrm{~m}^{-1} \mathrm{~K}^{-1}$ dla temperatury $300 \mathrm{~K}$ i ciśnienia $1 \mathrm{~atm}$ oraz próżni. Zależność $K(P)$ wskazuje wartości $K$ wynoszące $1,3 \mathrm{~W} \mathrm{~m}^{-1} \mathrm{~K}^{-1}$ w $300 \mathrm{~K}$ oraz
$1,1 \mathrm{~W} \mathrm{~m}^{-1} \mathrm{~K}^{-1} \mathrm{~W} 200 \mathrm{~K}$ dla próżni. Średnia wartość przewodności cieplnej chondrytu Jezersko dla wszystkich przewidywań wynosi w przypadku temperatury $\sim 300 \mathrm{~K}$ i ciśnienia powietrza $1 \mathrm{~atm}: 2,4 \pm 0,3 \mathrm{~W} \mathrm{~m}^{-1} \mathrm{~K}^{-1}$, a w przedziale temperatur 200-300 K i próżni: $1,4 \pm 0,4 \mathrm{~W} \mathrm{~m}^{-1} \mathrm{~K}^{-1}$. Przewodność cieplna meteorytu Jezersko znajduje się w zakresie chondrytów grupy H i jest bliska wartościom przewodności cieplnej innych chondrytów grupy H, m.in. Metsäkylä i Pułtusk.

\section{Podziękowania}

Autor serdecznie dziękuje Recenzentom za cenne uwagi i sugestie dotyczące prezentacji wyników badań.

\section{Literatura}

Clauser C., Huenges E., 1995. Thermal conductivity of rocks and minerals. [W:] Ahrens T.J. (ed.). Rock physics \& phase relations. A handbook of physical constants, volume 3. American Geophysical Union, Washington, DC: 105-126.

Drury M.J., Jessop A.M., 1983. The estimation of rock thermal conductivity from mineral content. An assessment of techniques. Zentralbl. Geol. Palaeontol., 1: 35-48. 
Farouki O.T., 1986. Thermal properties of soils. Trans Tech Publications, Clausthal-Zellerfeld.

Flynn G.J., Consolmagno G.J., Britt D.T., Brown P., Macke R.J., 2018. Physical properties of the stone meteorites: Implications for the properties of their parent bodies. Chemie der Erde, 78(3): 269-298. DOI: 10.1016/j.chemer.2017.04.002.

Fuchs S., Balling N., Förster A., 2015. Calculation of thermal conductivity, thermal diffusivity and specific heat capacity of sedimentary rocks using petrophysical well logs. Geophysical Journal International, 203(3): 1977-2000. DOI: 10.1093/gji/ggv403.

Fuchs S., Schütz F., Förster H.J., Förster A., 2013. Evaluation of common mixing models for calculating bulk thermal conductivity of sedimentary rocks: Correction charts and new conversion equations. Geothermics, 47: 40-52.

Griffiths C.M., Brereton N.R., Beausillon R., Castillo D., 1992. Thermal conductivity prediction from petrophysical data: a case study. [W:] Hurst A., Griffiths C.M., Worthington P.F. (eds.). Geological Applications of Wireline Logs II. GSSP Spec. Publ. 65: 299-315.

Hashin Z., Shtrikman S., 1962. A variational approach to the theory of the effective magnetic permeability of multiphase materials. Journal of Applied Physics, 33: 3125-3131. DOI: 10.1063/1.1728579.

Henke S., Gail H.P., Trieloff M., 2016. Thermal evolution and sintering of chondritic planetesimals III. Modelling the heat conductivity of porous chondrite. Astronomy \& Astrophysics, 589: A41. DOI: 10.1051/0004-6361/201527687.

Henke S., Gail H.P., Trieloff M., Schwartz W.H., Kleine T., 2012. Thermal history modeling of the $\mathrm{H}$ chondrite parent body. Astronomy \& Astrophysics, 545: A135. DOI: 10.1051/0004-6361/201219100.

Ho C.Y., Ackerman M.W., Wu K.Y., Oh S.G., Havill T.N., 1978. Thermal conductivity of ten selected binary alloy systems. Journal of Physical and Chemical Reference Data, 7: 959-1178. DOI: 10.1063/1.555583.

Łuszczek K., Przylibski T.A., 2019. Potential deposits of selected metallic resources on L chondrite parent bodies. Planetary and Space Science, 168: 40-51. DOI: 10.1016/j.pss.2019.02.005.

Matsui T., Osako M., 1979. Thermal property measurement of Yamato meteorites. Memoirs of National Institute of Polar Research (Special Issue), 15: 243-252.

Miler M., Ambrožič B., Mitrič B., Gosar M., Šturm S., Dolenec M., Jeršek M., 2014. Mineral and chemical composition of the Jezersko meteorite - a new chondrite from Slovenia. Meteoritics \& Planetary Science, 49: 1875-1887. DOI: 10.1111/maps.12365.

Nobes D.C., Villinger H., Davis E.E., Law L.K., 1986. Estimation of marine sediment bulk physical properties at depth from seafloor geophysical measurements. Journal of Geophysical Research, 91: 14033-14043. DOI: 10.1029/JB091iB14p14033.

Opeil C.P., Britt D.T., Macke R.J., Consolmagno G.J., 2020. The surprising thermal properties of CM carbonaceous chondrites. Meteoritics \& Planetary Science, 55(8). DOI: 10.1111/maps.13556.

Opeil C.P., Consolmagno G.J., Britt D.T., 2010. The thermal conductivity of meteorites: new measurements and analysis. Icarus, 208: 449-454. DOI: 10.1016/j.icarus.2010.01.021.

Opeil C.P., Consolmagno G.J., Safarik D.J., Britt D.T., 2012. Stony meteorite thermal properties and their relationship to meteorite chemical and physical states. Meteoritics \& Planetary Science, 47: 319-329. DOI: 10.1111/j.1945-5100.2012.01331.x.
Osako M., 1981. Thermal diffusivity measurements of chondrites and iron meteorite. Bulletin of the National Science Museum Tokyo, Ser. E, 4 Dec., 22: 1-8.

Ostrowski D., Bryson K., 2019. The physical properties of meteorites. Planetary and Space Science, 165: 148-178. DOI: 10.1016/j. pss.2018.11.003.

Plewa M., Plewa S., 1992. Petrofizyka. Wydawnictwo Geologiczne, Warszawa.

Przelaskowska A., 2018. Szacowanie wartości współczynnika przewodności cieplnej piaskowców fliszowych na podstawie składu mineralnego. Nafta-Gaz, 6: 435-442. DOI: 10.18668/NG.2018.06.03.

Schön J.H., 2011. Physical Properties of Rocks, A Workbook. Ch. 9, Handbook of Petroleum Exploration and Production. vol. 8. Wyd. Elsevier, Amsterdam.

Soini A.-J., Kukkonen I.T., Kohout T., Luttinen A., 2020. Thermal and porosity properties of meteorites: A compilation of published data and new measurements. Meteoritics \& Planetary Science, 55(2): 402-425. DOI: 10.1111/maps.13441.

Szewczyk J., 2001. Estymacja gęstości strumienia cieplnego metodą modelowań właściwości termicznych ośrodka. Przegląd Geologiczny, 49(11): 1083-1088.

Szewczyk J., Gientka D., 2009. Terrestrial heat flow density in Poland - a new approach. Geological Quarterly, 53(1): 125-140.

Szurgot M., 2011. Thermal conductivity of meteorites. Meteoritics \& Planetary Science, 46 Suppl.: A230.

Szurgot M., 2019. Średni ciężar atomowy i gęstość ziaren chondrytu Jezersko (H4). Acta Societatis Metheoriticae Polonorum, 10: 140-159.

Szurgot M., 2020a. Ciepło właściwe i ciepło atomowe chondrytu Jezersko. Przeglad Geologiczny, 68: 54-59. DOI: 10.7306/2020.1.

Szurgot M., 2020b. Średni ciężar cząsteczkowy chondrytu Jezersko (H4). Promień i objętość atomu i cząsteczki chondrytu. Acta Societatis Metheoriticae Polonorum, 11: 98-109.

Szurgot M., Wojtatowicz T.W., 2011. Thermal diffusivity of meteorites. Meteoritics \& Planetary Science, 46 Suppl.: A230.

Walsh J.B., Decker E.R., 1966. Effect of pressure and saturating fluid on the thermal conductivity of compact rock. Journal of Geophysical Research, 71: 3053-3061. DOI: 10.1029/JZ0711012p03053.

Woodside W., Messmer J.H., 1961. Thermal conductivity of porous media. Journal of Applied Physics, 32(9): 1688-1706. DOI: $10.1063 / 1.1728419$.

Yomogida K., Matsui T., 1983. Physical properties of ordinary chondrites. Journal of Geophysical Research, 88: 9513-9533. DOI: 10.1029/JB088iB11p09513.

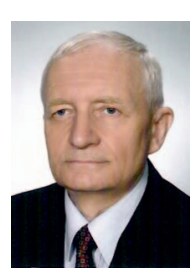

Dr Marian A. SZURGOT

Starszy wykładowca (emerytowany)

Centrum Nauczania Matematyki

i Fizyki Politechniki Łódzkiej

al. Politechniki 11

90-924 Łódź

E-mail:maszurgot@gmail.com 